\title{
Seasonal and spatial root biomass and water use efficiency of four forage legumes in semiarid northwest China
}

\author{
Bingcheng $\mathrm{Xu}^{1,2}$, Lun Shan ${ }^{2}$, Fengmin $\mathrm{Li}^{1,2 *}$ and Jun Jiang ${ }^{2}$ \\ ${ }^{1}$ MOE Key Laboratory of Arid and Grassland Ecology, Lanzhou University, Lanzhou 730000, China. \\ ${ }^{2}$ State Key Laboratory of Soil Erosion and Dryland Farming on Loess Plateau, Institute of Soil and Water Conservation, \\ Chinese Academy of Sciences, Northwest A \& F University, Yangling 712100, China.
}

Accepted 8 November, 2007

\begin{abstract}
A field study was conducted to determine seasonal root biomass, root spatial distribution and water use efficiency (WUE) in milkvetch (Astragalus adsurgens Pall.), sainfoin (Onobrychis viciaefolia Scop.), alfalfa (Medicago sativa L.) and Lespedeza davurica (L. davurica) grown in semiarid region on the Loess Plateau, northwestern China. Soil core method $(\varnothing 9 \mathrm{~cm})$ was used to determine root biomass in April, September and November in 2005. For each species, root biomass vertical distribution was measured down to $150 \mathrm{~cm}$ in increments of $0-20,20-40,40-60,60-90,90-120$ and $120-150 \mathrm{~cm}$ for inter-rows, between plants and at the center of plants respectively. Roots were distributed throughout the profile with a high concentration at the top and decreasing with soil depth. Root biomass was mainly concentrated in $0-60 \mathrm{~cm}$ strata between rows and between plants of each species while at the center of plants it mainly distributed in $0-20 \mathrm{~cm}$ strata. Except $L$. davurica whose root biomass reached the maximum in September, root biomass of the other three legumes reached the maximum in November. Shoot biomass continued to increase from April to November for all the four legumes. In November, the root biomass for milkvetch and alfalfa accounted for about 2.93 and $2.30 \%$ of the total biomass (root plus shoot) respectively, while in sainfoin and $L$. davurica it accounted for 6.00 and $4.44 \%$ respectively. There were significant differences between the four legumes in WUE, and the order was same as shoot biomass, ranked as milkvetch>alfalfa>sainfoin $>L$. davurica. The seasonal and yearly high shoot biomass and low proportion of root biomass resulting to low root : shoot ratio may explain the significantly higher WUE of milkvetch and alfalfa in comparison to sainfoin and $L$. davurica.
\end{abstract}

Key words: Root biomass and distribution root: shoot ratio, water use efficiency (WUE), legume, Loess Plateau.

\section{INTRODUCTION}

Roots play an important role in maintaining water and nutrient supply to plant tissues, and they also contribute in the maintenance of soil organic matter content and structure (Pietola and Alakukku, 2005). Differences in rooting depth and root density exist in many crop species (Smit et al., 1994). Rooting pattern differences existing in nature are the result of both genetically and environmen-

*Corresponding author. E-mail: fmli@lzu.edu.cn, Tel: +86-9318912848. tally determined characteristics (Neukirchen et al., 1999). Because of site conditions, developmental stage and genotype, root systems show wide variations both between and within species, which lead to variations in the efficiency of water and nutrient uptake (Kirkham et al., 1998; Neukirchen et al., 1999). Crop specific information about root dynamics and root system size will greatly assist the estimation of the water and nutrient uptake and eco-adaptation in different plant species (Synman, 2005). Root data has become more significant important in evaluating environmental impacts of agriculture (Campbell and de Jong, 2001), especially in arid and 
Table 1. Monthly rainfall (mm) in 2005 and 50-year (1951-2000) mean.

\begin{tabular}{|c|c|c|c|c|c|c|c|c|c|c|c|c|c|}
\hline \multicolumn{1}{|c|}{ Year } & Jan & Feb & Mar & Apr & May & Jun & Jul & Aug & Sep & Oct & Nov & Dec & Total \\
\hline 2005 & 0 & 2.2 & 2.4 & 14.4 & 95.2 & 40.0 & 213.6 & 57.2 & 103.6 & 12.8 & 0 & 0 & 541.4 \\
\hline $1951-2000$ & 3.5 & 5.8 & 15.0 & 24.5 & 48.8 & 75.3 & 119.9 & 123.6 & 76.3 & 33.3 & 8.5 & 3.2 & 537.7 \\
\hline
\end{tabular}

semi-arid regions.

Forage legumes have significant roles in agricultural development because their ability of fixing nitrogen and they are used for high quality feed in the intensive livestock systems (Shan and Chen, 1993; Drinkwater et al., 1998). For decades, perennial legumes such as alfalfa (Medicago sativa L.), sainfoin (Onobrychis viciaefolia Scop.) and milkvetch (Astragalus adsurgens Pall.) have been used in China as palatable forages and widely cultivated in diverse environments in China (Shan and Chen, 1993; Gao et al., 2001). Lespedeza davurica ( $L$. davurica) is a widely spread species and has been identified as a valuable fodder due to high adaptability and quality in semiarid northwest China. Considerable research has been conducted in comparing the biomass production and water use characteristics between these four legumes (Shan and Chen, 1993; Xu et al., 2006). Therefore, little quantitative information on root growth and distribution among them has been reported. In the present study, root biomass dynamics and distribution in soil of four leguminous forages was investigated on a 5year experimental field. The objectives were (1) to compare seasonal root distribution and coarse root biomass of the four legumes; and (2) to study the root: shoot ratio dynamics in relation to water use characteristics. These parameters are important links to our larger goal of choosing suitable legumes for the area and investigate their environmental impacts on soil quality and water use after long-term planting.

\section{MATERIALS AND METHODS}

\section{Study site description}

Field studies were conducted in 2005 on a lowland farmland at Ansai Research Station (ARS) of Chinese Academy of Science (CAS) located at grid reference $36^{\circ} 51^{\prime} 30^{\prime \prime} \mathrm{N}, 109^{\circ} 19^{\prime} 23^{\prime \prime} \mathrm{E}$ and altitude 1068 a.s.l. The mean annual precipitation of the area is about $537.70 \mathrm{~mm}$ (1951 - 2000), while rainfall recorded in 2005 was $541.40 \mathrm{~mm}$. In the area, rainfall during the growth season from April to October accounts for 85 - 95\% of the annual total, while July to September, which is always considered the rainy season, accounts for $60-80 \%$. In 2005, the rainfall in the growth and rainy season accounted for 99.00 and $69.20 \%$ of yearly rainfall respectively (Table 1). The average annual temperature in the area is $8.80^{\circ}$, with extremes of $-6.90^{\circ}$ in January and $22.60^{\circ}$ in July. The loessial soil is characterized as silt loam, highly calcareous in nature $(\mathrm{pH} 8.40)$, deep $(50-80 \mathrm{~m})$, low organic carbon $(0.55 \%)$, low available $\mathrm{N}(50$ $\mathrm{mg} / \mathrm{kg})$, low available $\mathrm{P}(1.70 \mathrm{mg} / \mathrm{kg})$, and high in available $\mathrm{K}$. Agriculture is rain-fed and the main crops are foxtail millet (Setaria italica) and potato (Solanum tuberosum). The cropping systems are annual spring or summer crop-winter fallow.

\section{Field experiment design}

The experimental field was previously planted with apple trees (Malus domestica) between 1992 and 1997. The growing of apple was stopped in October 1997. The field was prepared for this experiment at late autumn of 2000 and it was left fallow for winter moisture accumulation. Sixteen experiment plots of $7 \mathrm{~m} \times 6 \mathrm{~m}$ were established with a $15 \mathrm{~cm}$ distance between the plots. The planting was done in early May of 2001, where four leguminous forage species, milkvetch (Astragalus adsurgens Pall, Super early milkvetch cv.), alfalfa (Medicago sativa L.), sainfoin (Onobrychis viciaefolia Scop) and Lespedeza davurica were dotted sowed. The space between two dots is $15 \mathrm{~cm}$. Each legume was sowed as monoculture on four experiment plots and the row spacing was put at $30 \mathrm{~cm}$. Fertilizers N, P and $\mathrm{K}$ were applied prior to plow the plots at a rate of $60 \mathrm{~N} \mathrm{~kg} / \mathrm{ha}, 45 \mathrm{P} \mathrm{kg} / \mathrm{ha}$, and $45 \mathrm{~K} \mathrm{~kg} / \mathrm{ha}$. There was no irrigation or any other form of water supplement over the whole fiveyear experimental period. All the experimental plots were harvested at the end of growth season every year.

\section{Shoot and root sampling}

Aboveground biomass samples were determined by cutting the plants with hand-held shears to ground level. For each species, the measurement was made on three sampling areas randomly chosen (three replications) from the four plots. The sampling areas were not used twice. To reduce the edge effect, the samples were taken about six rows from the plot border. Total aboveground biomass of each species was considered the sum of dry litter and standing parts. For each species, standing aboveground biomass parts were sampled from $50 \mathrm{~cm}$ section in each of three proximate rows.

Root samples were taken by auger method $(\varnothing 9 \mathrm{~cm})$. The sampling on the $4^{\text {th }}$ September and $4^{\text {th }}$ November were for both the root and aboveground biomass measurements while the one for the $4^{\text {th }}$ April before sprouting was only for root biomass measurement. The core samples were taken up to a soil depth of $150 \mathrm{~cm}$, which were divided into 6 segments as 0 - 20, 20 - 40, 40 - 60, 60 - 90, 90 - 120 , and $120-150 \mathrm{~cm}$. Three replicate samples systematically distributed over each plot were taken between rows, on plants and the mid point between the rows respectively after shoot sampling (Figure 1). The samples were taken to the laboratory and rinsed free of soil on two sieves, 1 and $0.50 \mathrm{~mm}$ mesh. No attempt was made to distinguish between live and dead roots. Plant samples were dried in a forced draft oven at $65^{\circ} \mathrm{C}$ for $24 \mathrm{~h}$ and weighed.

It was assumed that root coverage underground was a $30 \mathrm{~cm} \times 15$ $\mathrm{cm}$ rectangle according to the row and plant spacing, so root biomass per unit ground area $\left(\mathrm{g} / \mathrm{m}^{2}\right)$ would be

Root biomass (RB) per unit ground area $\left(\mathrm{g} / \mathrm{m}^{2}\right)$

$\mathrm{RB}=\frac{0.3 \times 0.15 \times \sqrt{(a+b)^{2}+(a+c)^{2}}}{4 \pi R^{2}}$

where $a, b$ and $c$ were root biomass measured at the center of plants, inter-rows and between plants of each legume respectively, and $R$ was the soil auger radius $(0.045 \mathrm{~m})$ (Figure 1$)$. 


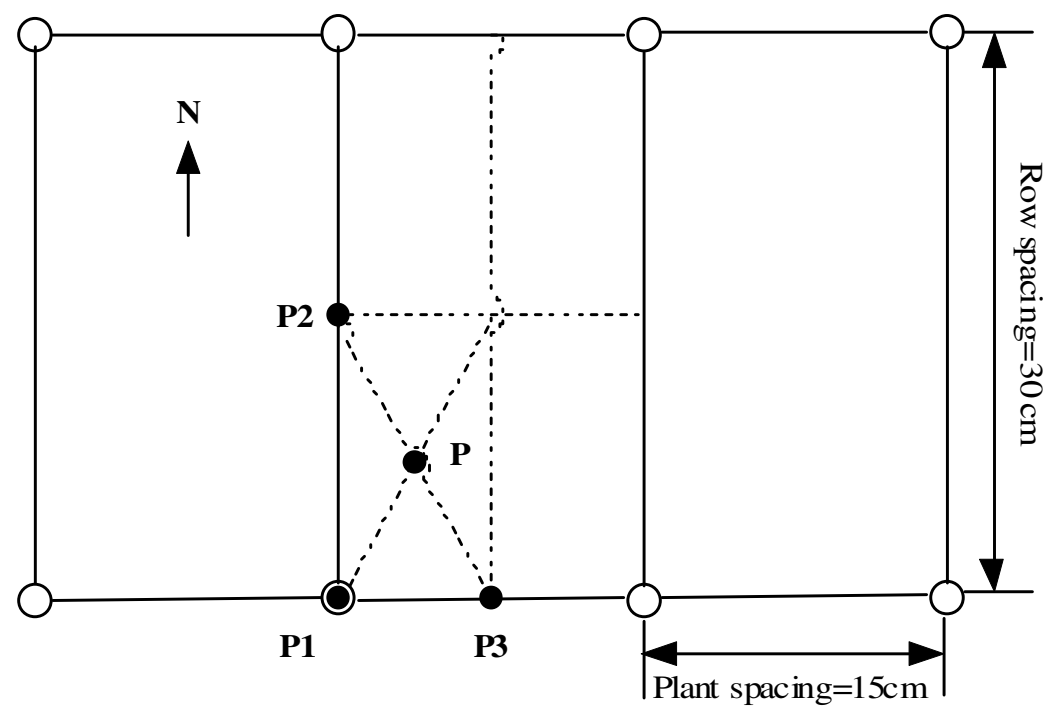

Figure 1. Sampling scheme for the core method $(P 1=$ center of plant, $P 2=$ center of tow rows and P3 = midway between two plants). Open circles represent individual plant of each legume. $\mathrm{P}$ is the corresponding representative for the calculation of root weight, and which is calculated as $\frac{\sqrt{(P 1+P 2)^{2}+(P 1+P 3)^{2}}}{4}$.

\section{Soil water content}

Soil water content measurements were made using soil core sampler ( $\varnothing 4 \mathrm{~cm}$ cores) every $20 \mathrm{~cm}$ to a depth of $500 \mathrm{~cm}$ at the same time with plant sampling. The sampling site was at the center of two rows in each species with three replicates. The soil water content $(\varnothing \%)$ was determined by the analysis of soil gravimetric water content where soil sample was dried at $105^{\circ} \mathrm{C}$ for $24 \mathrm{~h}$, and was calculated using the formula:

$(\varnothing \%)=\frac{(W w-W d)}{W d} \times 100 \%$

Where $W w$ and $W d$ were the wet and dry weight mass of soil samples.

\section{Water use efficiency}

Soil bulk density $(\tilde{\mathrm{N}})$ is $1.10 \mathrm{~g} \mathrm{~cm}^{-3}$ for $0-20 \mathrm{~cm}$ layer and $1.30 \mathrm{~g}$ $\mathrm{cm}^{-3}$ for below $20 \mathrm{~cm}$ respectively (Xu et al., 2006). The deep drainage was considered negligible and no runoff was allowed from the experimental plots (Xu et al., 2006). Evapotranspiration (ET, $\mathrm{mm}$ ) was calculated as the total rainfall during the crop growing season plus the difference in soil water between two soil water content measurements, which was determined according to the equation

$E T=P+Q W W$

Where oW was the change in water stored in the profile between 0 and $500 \mathrm{~cm}$ in the period considered, and $P$ was the rainfall. Rainfall was recorded at a weather station about $100 \mathrm{~m}$ from the experimental fields. Water-use efficiency (WUE) $\left(\mathrm{g} / \mathrm{m}^{2} / \mathrm{mm}\right.$ ) was defined as the amount of biomass produced per unit volume of water evapo-transpired (Fuentes et al., 2003). In this study, WUE was calculated for aboveground (WUEab) and total biomass (WUEtb) (yearly increase of aboveground biomass plus root biomass in September and November compared with April, respectively) separately.

\section{Statistical analysis}

The seasonal root and shoot biomass production as well as the change and WUE of each legume were statistically analyzed with One-way ANOVA at $\mathrm{P}=0.05$.

\section{RESULTS}

\section{Shoot and root biomass}

The ranking of shoot biomass for the four legumes in September and November were same, which were milkvetch > alfalfa $>$ sainfoin $>L$. davurica, and there were significant differences between two species (Table 2). In April, the differences between the four legumes in root biomass in the $1.50 \mathrm{~m}$ soil profile were significant, where alfalfa was the highest and milkvetch the lowest (Table 2). Root biomass in September increased significantly as compared with that in April, and the increase was doubled in milkvetch and $L$. davurica. There was a significant increase in root biomass from September to November for milkvetch, alfalfa and sainfoin, while $L$. davurica decreased significantly (Table 2). In September, root biomass accounted for about 1.41 and $1.19 \%$ of the total biomass (root plus shoot) for milkvetch and alfalfa respectively, while for sainfoin and 
Table 2. Root and shoot biomass $\left(\mathrm{g} / \mathrm{m}^{2}\right)$ for the four species in 2005 (mean $\pm \mathrm{SE}$ ).

\begin{tabular}{|c|c|c|c|c|c|c|}
\hline Species & \multicolumn{3}{|c|}{ A. adsurgens } & \multicolumn{3}{|c|}{ O. viciaefolia } \\
\hline Month & Apr. & Sept. & Nov. & Apr. & Sept. & Nov. \\
\hline Shoot & - & $1185.9 \pm 26.6$ & $1248.3 \pm 26.8$ & - & $788.8 \pm 17.7$ & $876.4 \pm 13.3$ \\
\hline Root & $14.1 \pm 1.1$ & $31.1 \pm 2.1$ & $51.8 \pm 3.6$ & $67.4 \pm 6.2$ & $95.3 \pm 5.6$ & $123.3 \pm 7.5$ \\
\hline Total & $14.1 \pm 1.1$ & $1217 \pm 96.8$ & $1300.1 \pm 36.8$ & $67.4 \pm 6.2$ & $884.1 \pm 10.9$ & $999.7 \pm 13.6$ \\
\hline Species & \multicolumn{3}{|c|}{ M. sativa } & \multicolumn{3}{|c|}{ L. davurica } \\
\hline Month & Apr. & Sept. & Nov. & Apr. & Sept. & Nov. \\
\hline Shoot & - & $979.2 \pm 13.7$ & $1088.0 \pm 6.2$ & - & $486.8 \pm 16.3$ & $496.8 \pm 15.1$ \\
\hline Root & $70.7 \pm 4.6$ & $82.5 \pm 6.8$ & $96.3 \pm 6.4$ & $19.1 \pm 2.9$ & $51.2 \pm 4.8$ & $42.2 \pm 3.8$ \\
\hline Total & $70.7 \pm 4.6$ & $1061.7 \pm 9.8$ & $1184.3 \pm 10.6$ & $19.1 \pm 2.9$ & $538.0 \pm 19.6$ & $539.0 \pm 23.5$ \\
\hline
\end{tabular}

L. davurica it accounted for 3.42 and $6.19 \%$ respectively (Table 2). By extrapolating root biomass in April from November, root biomass accounted for $2.30-6.00 \%$ of total biomass production, sainfoin and $L$. davurica had larger root: shoot ratio (6.00 and $4.44 \%$ respectively) (Table 2).

\section{Root distribution}

Roots biomass was found throughout the $0-150 \mathrm{~cm}$ soil profiles for the four legumes (Figure 2). All the four legumes had similar root biomass distribution in the $0-$ $150 \mathrm{~cm}$ soil profile, and more than $94 \%$ of the root biomass was concentrated in the top $40 \mathrm{~cm}$ (Figure 3). At the sampling points of inter-rows (P2) and between plants (P3), the root biomass in the $0-60 \mathrm{~cm}$ strata accounted for more than $60 \%$ and decreased gradually with depth below $60 \mathrm{~cm}$. At the center of plants (P1), the $0-40 \mathrm{~cm}$ segment of the profile accounted for more than $80 \%$, while $0-20 \mathrm{~cm}$ strata accounted for more than $50 \%$ (Figure 2). Changes in root biomass distribution during the growth seasons were observed, for milkvetch in the 0 $-60 \mathrm{~cm}$ strata, while for the other three legumes it was 0 $-150 \mathrm{~cm}$ soil profile.

\section{Water use efficiency}

There was a significant difference between the four legumes in WUEab, and the order was milkvetch $>$ alfalfa $>$ sainfoin $>L$. davurica. The WUEab of milkvetch was about 1.3, 2.2 and 3.55 times of alfalfa, saifoin and $L$. davurica respectively (Figure 4). Because annual root biomass production was very small compared with shoot production, the WUEtb order was the same as WUEab and there was no significant difference between them (Figure 4).

\section{DISCUSSION}

The distribution and growth of roots from annual crops and trees have been intensively investigated (Siddique et al., 1990; Pietola and Alakukku, 2005), whereas the root patterns of perennial plants like these four legumes are not well known (Shan and Chen, 1993). The present study conducted on well established fields of the four leguminous in the $5^{\text {th }}$ year after planting was to give a general view of the spatial and temporal root distribution and the biomass production differences between them.

Water is the primary limiting factor for plant growth in semi-arid area on the Loess Plateau. The annual precipitation is relative small and seasonal distribution is variable, which will often restrict plant yields because of lack of water. The availability of water to individual plants in such environments depends on local climatic and edaphic factors as well as on the depth and lateral spread of plant root systems (Casper and Jackson, 1997; Schenk and Jackson, 2002). Options for plants to increase water available are to increase the root length in the deep sub-soil layers or concentrate to the soil surface (Shan and Chen, 1993). In the present study, the distribution of roots throughout the profile, with a high concentration at the top and decreasing with depth (Figures 2 and 3) was expected since such patterns have been reported in most other studies taken in dry areas (Synman, 2005).

Root biomass distribution on plants in different soil layers was significantly higher than inter-rows or between plants, which is consistent with leguminous taproot characteristics (Neukirchen et al., 1999). In the area, water deficit in the upper soil develops rapidly because of low and variable rainfall, which probably causes faster seasonal root desiccation and death, therefore most of the root biomass occurs within $0-60 \mathrm{~cm}$ soil profile, and only a minimal fraction reaches below that depth (Figures 3 and 4). Though root cores were not sampled deeper than $150 \mathrm{~cm}$, it should not have made a large difference in total root distribution characteristics.

The fluctuation of belowground biomass production within a growth season is a common problem concerning root studies (Shackleton et al., 1988; Synman, 2005). Most research to date supports the findings that root 
Root distribution inter-rows

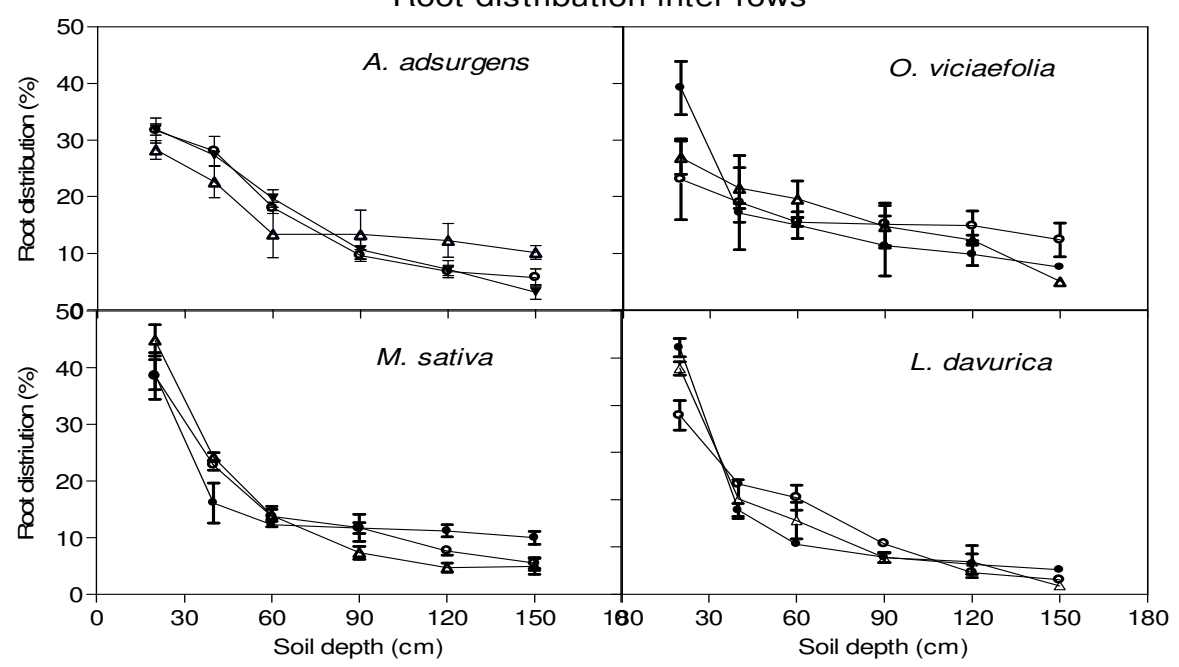

Root distribution between plants

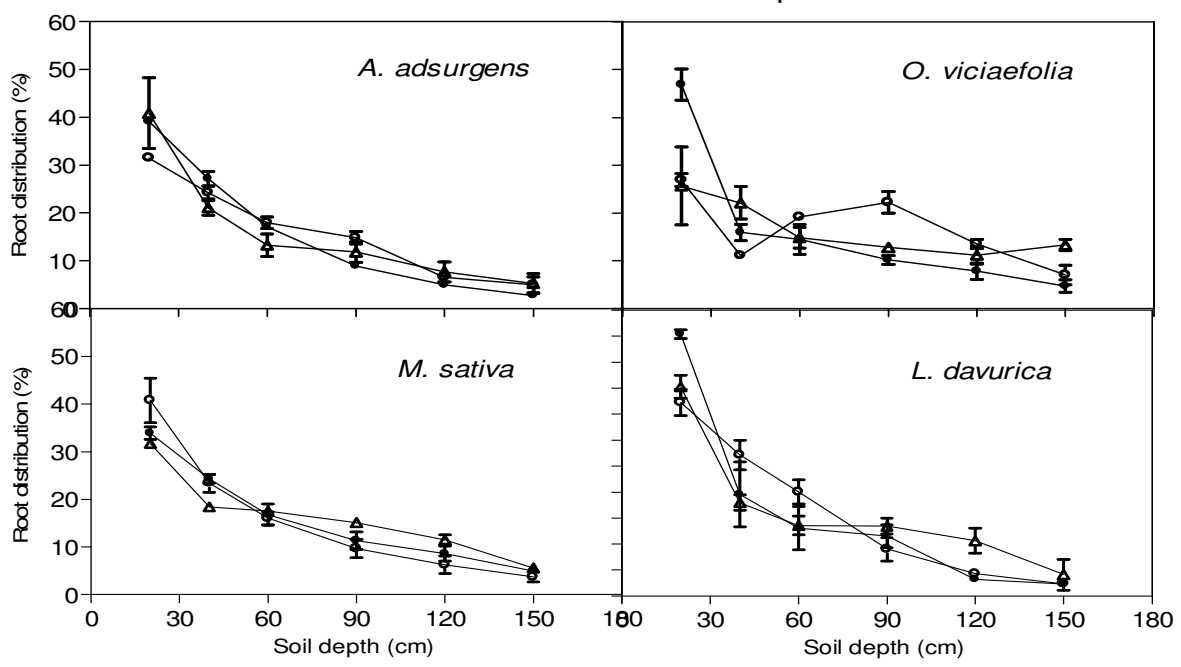

Root distribution at the center of plants

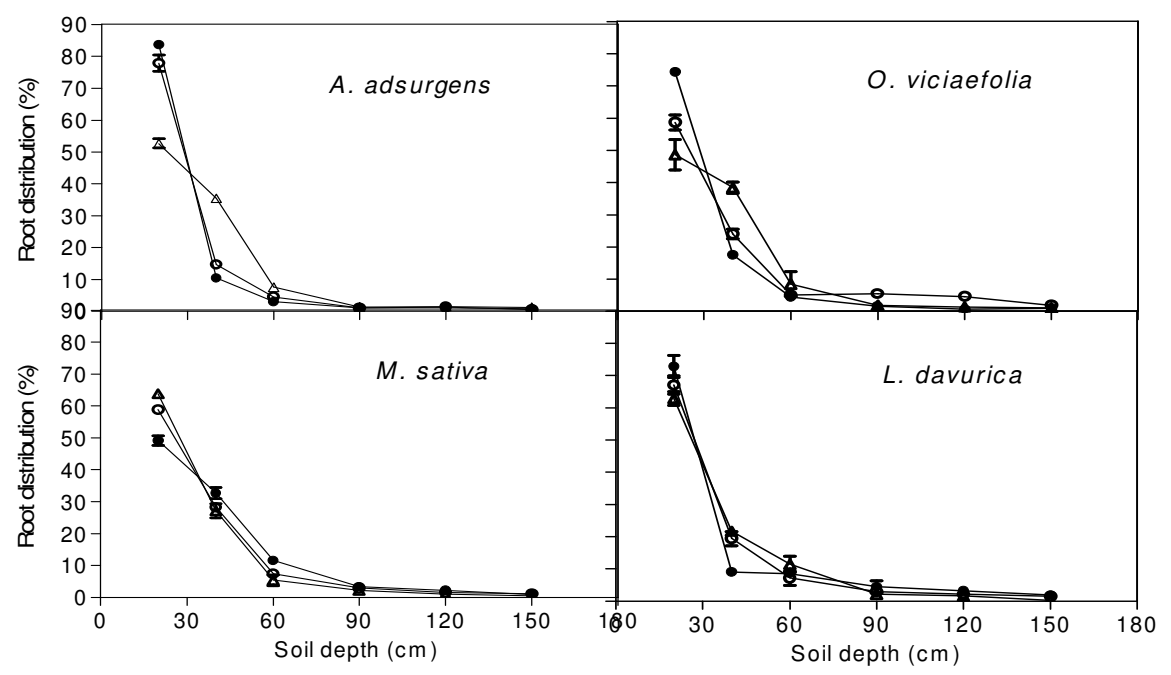

Figure 2. Average percentage root distribution with depth of soil of the four legumes for the three samplings in 2005 ( $n=3)$. ( $\square$ : April; ०: September; •: November). 

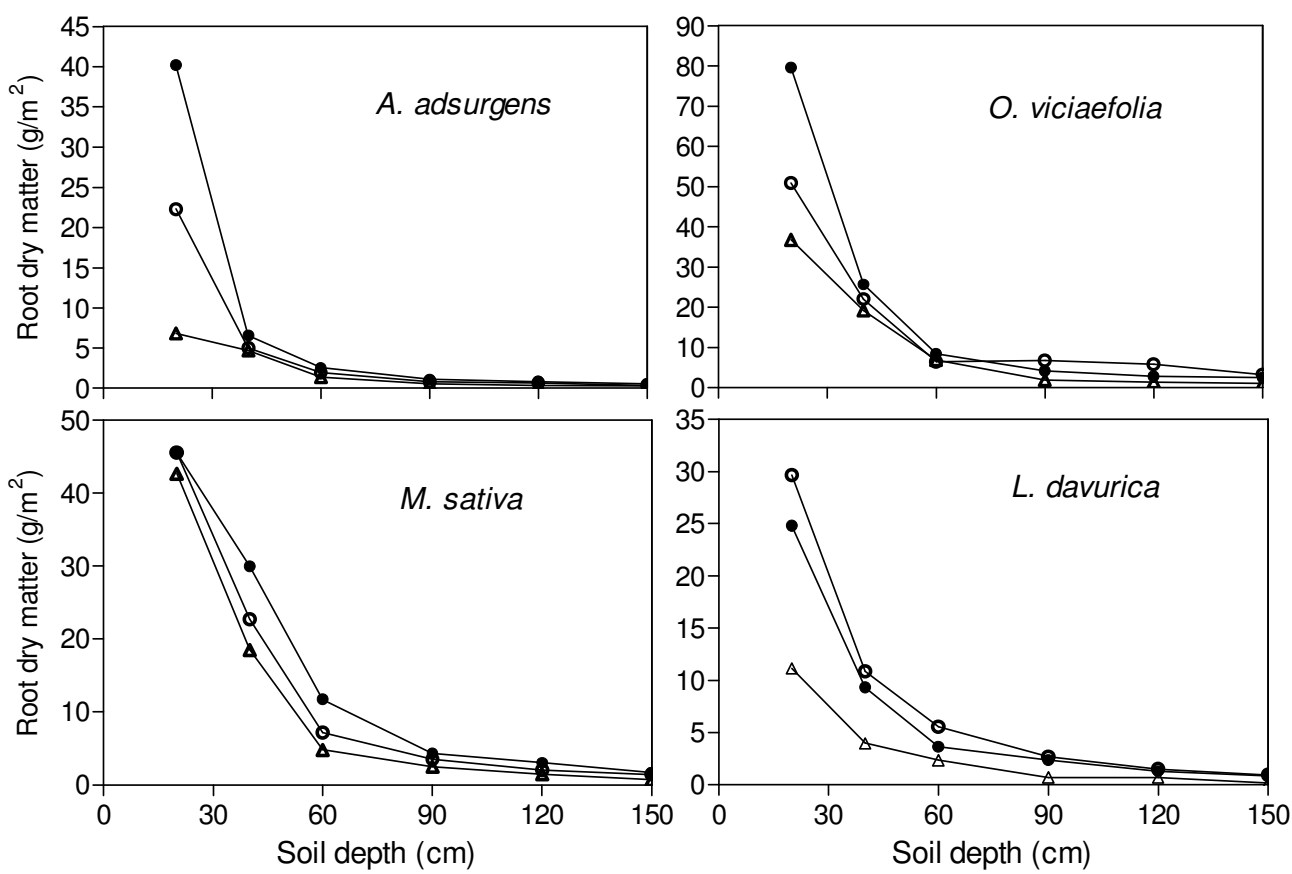

Figure 3. Root distribution in the soil profile of the four legumes in $2005(n=3)$. ( $\square$ : April; $\circ$ : September; $\bullet$ : November).

growth in grasses at sites with reasonably distinct wet and dry seasons is most rapid during late summer and early spring, with the greatest burst of growth during autumn (Synman, 2005). In our study, root biomass of the milkvetch, alfalfa and sainfoin accounted for most of the biomass accumulation during the last two months of growth season (September to November), which is characterized as autumn season in the area. L. davurica had some differences from the other three, and it had the highest root biomass before September (Table 2). This development of sinks may be responsible for its wild characteristics to absorb more rainwater during the rainy seasons.

In this study, the root : shoot ratios based on biomass production before September for milkvetch and alfalfa were only $0.01-0.03$, and those for sainfoin and $L$. davurica were about 0.04 - 0.07 (Table 2). This difference was responsible for the higher yearly WUEab of milkvetch and alfalfa (Figure 4). In general, highest WUE occurs with highest biomass, but is plant-specific (Fuentes et al., 2003). Milkvetch and alfalfa were more productive in aboveground biomass than sainfoin and $L$. davurica, and they had significantly higher shoot biomass and WUEab (Figure 4). The causes for this are the high efficiency in leaf water use in different seasons and also higher canopy coverage in reducing soil evaporation (Xu et al., 2006). Therefore, high ability in using deep soil water and great leaf WUE may also be the reasons for milkvetch and alfalfa to grow well in diverse and drought environments on the Loess Plateau of China (Shan and Chen, 1993; Gao et al., 2001).

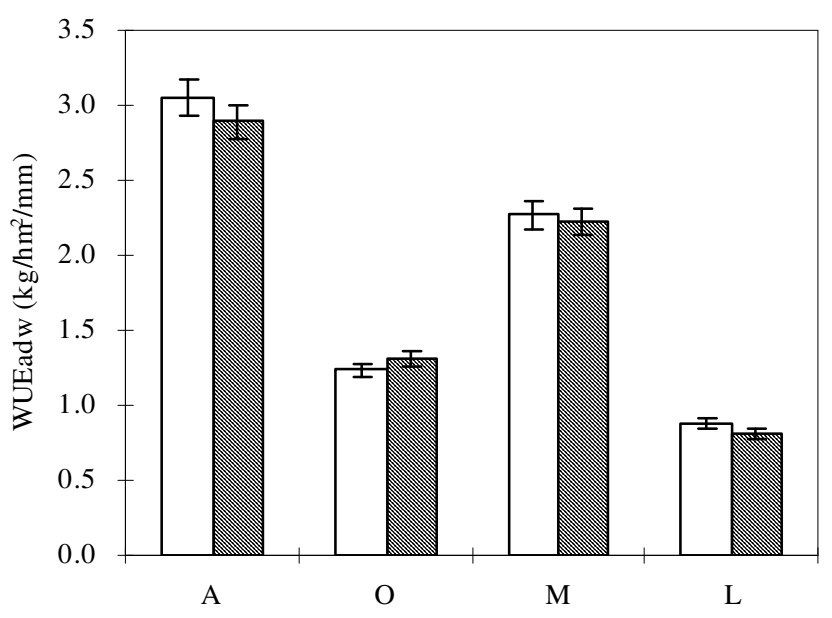

Figure 4. Water use efficiency of aboveground biomass (WUEab) (open bars) and total biomass (root plus shoot) (WUEtb) (stripped bars) of the four legumes at growth season terminated in 2005 (A: A. adsurgens; O: O. viciaefolia; M: M. sativa; L: L. davurica).

Root characteristics have received less attention than shoots because of the difficulties of extraction and quantification (Siddique et al., 1990). Despite these problems, there are many attractions in trying to breed for more efficient root systems (Siddique et al., 1990). For farmers, the aboveground biomass production, effective and sustainable soil water uses are mostly considered in arid or semiarid areas. Therefore, alfalfa and milkvetch 
are the best choice because of low root : shoot ratios and high WUE during the growth seasons. Distributed vertically and horizontally together with high proportion in root biomass of milkvetch in the top soil indicates high adaptation to the area, and verified it as efficient soil and water conservation species. L. davurica required much more water per unit of biomass (Figure 4). The reason why it could adapt to semiarid environment was not only the special root growth characteristics (Figures 2 and 3). Sainfoin had relative high WUE and the biggest net root production yearly, which could be used as green manure crop or rotation crop in the area.

\section{Conclusion}

In conclusions, water use efficiency (WUE) of the four legumes was correspondent with the shoot biomass production, ranked as milkvetch $>$ alfalfa $>$ sainfoin $>L$. davurica. About $94 \%$ of the total root biomass (0 - 150 $\mathrm{cm}$ ) was accumulated into the topsoil $(0-40 \mathrm{~cm})$ layer by these four species. The yearly net biomass production partition (root:shoot ratio) for sainfoin and $L$. davurica were significantly higher than for milkvetch and alfalfa. They also inputed large biomass in roots during April and September. Thus, sainfoin and $L$. davurica are more efficient soil $C$ sinks among these four legumes. However, the present study is deficient in the seasonal root turnover, fine roots growth and distribution, and soil $\mathrm{C}$ and $\mathrm{N}$ economy evaluation. Future studies should focus on these aspects.

\section{ACKNOWLEDGMENT}

This work was funded by the "Talent Training Project in West China" Programs of the CAS (No. 2006YB01).

\section{REFERENCES}

Campbell CA, Jong $R$ de (2001). Root-to-straw ratios-influence of moisture and rate of $N$ fertilizer. Can. J. Soil Sci., 81: 39-43.

Casper BB, Jackson RB (1997). Plant competition underground. Ann. Rev. Ecol. Syst., 28: 545-570.
Drinkwater LE, Wagoner P, Sarrantonio M (1998). Legume-based cropping systems have reduced carbon and nitrogen losses. Nature, 396: 262-264.

Fuentes JP, Flury M, Huggins DR, Bezdicek DF (2003). Soil water and nitrogen dynamics in dryland cropping systems of Washington State, USA. Soil Till. Res., 71: 33-47.

Gao JL, Terefeworkb Z, Chen WX, Lindstrom K (2001). Genetic diversity of rhizobia isolated from Astragalus adsurgens growing in different geographical regions of China. J. Biotechnol., 91: 155-168.

Kirkham MB, Grecu SJ, Kanemasu ET (1998). Comparisons of minirhizotrons and the soil-water-depletion method to determine maize and soybean root length and depth. Eur. J. Agron., 8,117-125.

Neukirchen D, Himken M, Lammel J, Czypionka-Krause U, Olfs HW (1999). Spatial and temporal distribution of the root system and root nutrient content of an established Miscanthus crop. Eur. J. Agron., 11: 301-309.

Pietola L, Alakukku L (2005). Root growth dynamics and biomass input by Nordic annual field crops. Agric. Ecosyst. Environ., 108: 135-144.

Schenk HJ, Jackson RB (2002). Rooting depths, lateral root spreads and below-ground/above-ground allometries of plants in water-limited ecosystems. J. Ecol., 90: 480-494.

Shackleton CM, McKenzie B, Granger JE (1988). Seasonal changes in root biomass, root/shoot ratios and turnover in two coastal grassland communities in Transkei. S. Afr. J. Bot., 54: 465-471.

Shan L, Chen GL (1993). Theory and practice of dryland farming on the Loess Plateau, Beijing: Chinese Science Press, pp. 256-280 (in Chinese).

Siddique KHM, Belford PK, Tennant D (1990). Root: shoot ratios of old and modern, tall and semi-dwarf wheats in a Mediterranean environment. Plant Soil, 121: 89-98.

Smit AL, Groenwold J, Vos J (1994). The Wageningen rhizolab-a facility to study soil-root-shoot-atmosphere interactions in crops. II. Methods of root observations. Plant Soil 161: 289-298.

Synman HA (2005). Rangeland degradation in a semi-arid South Africa.I: Influence on seasonal root distribution, root/shoot ratios and water-use efficiency. J. Arid Environ., 60: 457-481.

Xu BC, Gichuki P, Shan L, Li FM (2006). Aboveground biomass production and soil water dynamics of four leguminous forages in semiarid region, northwest China. S. Afr. J. Bot., 72: 507-516. 